\title{
Energy exchanges and injury
}

By J. R. Richards and J. K. DruRY, University Department of Surgery, Glasgow Royal Infirmary and The Institute of Physiology, The University of Glasgow and C. Goll and R. G. Bessent, West of Scotland Health Boards, Department of Clinical Physics and Bioengineering and Department of Nuclear Medicine, Glasgow Royal Infirmary and G. A. A. AL-Shamma, The Department of Pathological Biochemistry, Glasgow Royal Infirmary, Glasgow $G_{4} \circ S F$

The practical application of calorimetry to the study of energy expenditure after injury did not begin until 1930, with the work of Cuthbertson in Glasgow, who used relatively crude indirect calorimetry techniques to study patients with bone fractures. During the late recovery phase, he found increases in oxygen consumption of $15-25 \%$ above resting values, associated with a rise in rectal temperature (Cuthbertson, 1932). These increases in metabolic expenditure were linked with evidence of increased protein breakdown (Cuthbertson, 1930, 1931), thought to originate in muscle (Cuthbertson, 1936). The injured rat displayed similar changes (Cuthbertson, 1939). Over the next two decades interest in the energetic consequences of injury waned, largely as a result of the poor accuracy and cumbersome nature of the calorimeters then available. Using radioisotope tracers and other advances, research into the metabolic response to injury centered upon biochemical, hormonal and cellular changes (Richards, 1977). Further indirect calorimetry studies were made (Cope, Nardi, Quijano, Rovit, Stanbury \& Wright, 1953) in the early 1950s but they could not identify the cause of the hypermetabolism following injury.

Advances in the study of energy expenditure after injury did not take place until the development of gradient-layer calorimetry (Benzinger \& Kitzinger, 1949). The adiabatic principles which had been responsible for the slow response time and relatively poor performance of earlier calorimeters were replaced by direct measurement of the instantaneous flow of heat through the walls of the chamber. The sensible and insensible heat loss of the subject could be measured continuously and automatically. A calorimeter of the Benzinger type was constructed at the Rowett Research Institute (Pullar, 1956, 1957, 1969), and later was used by Cairnie, Campbell, Cuthbertson \& Pullar (1957) to measure energy expenditure after bone fracture in groups of rats. They found increases in metabolic rate of up to $7 \%$ above normal resting values in rats kept at an ambient temperature of $19^{\circ}$ after unilateral femur fracture. By direct and indirect measurement, the total metabolism of rats fed on $18.1 \%$ protein diet was $608 \mathrm{~kJ} / \mathrm{kg}^{0.75}$ per $\mathrm{d}$ before injury. This increased to a maximum of $637 \mathrm{~kJ} / \mathrm{kg}^{0.75}$ per $\mathrm{d}$ on the third post fracture day and was closely paralleled by an increase in urinary nitrogen losses from $360 \mathrm{mg} / \mathrm{d}$ before, to a maximum of $478 \mathrm{mg} / \mathrm{d}$ on the third day after injury. The calculated 
energy provided by oxidation of the quantity of protein was $126 \mathrm{~kJ} / \mathrm{kg}^{0.75}$ per $\mathrm{d}$ before and $155 \mathrm{~kJ} / \mathrm{kg}^{0.75}$ per $\mathrm{d}$ after injury. This difference was exactly sufficient to explain the $29 \mathrm{~kJ}$ increase in total metabolic expenditure measured by calorimetry. There was no evidence of an increase in fat or carbohydrate metabolism, and it was concluded that the post-injury increase in resting metabolism was theat resulting from the process of deamination of protein amino acids and from the use of the non-nitrogenous residue as a source of energy' causing a form of endogenous specific dynamic action. Catabolism of muscle protein stores in these circumstances was seen as an obligatory part of our primitive metabolic response to severe injury providing energy and water to sustain life and to repair tissues, where the ability to provide adequate nutrition might be restricted.

Cairnie's views on the importance of post-injury protein catabolism were challenged by Miksche \& Caldwell (1967) who studied energy expenditure after severe bone injury in the rat using a specially constructed, gradient-layer calorimeter (Caldwell, Hammel \& Dolan, r966). After bone fracture, fasted male albino rats had a significant increase of $14.20 \%$ in heat production with increased sensible heat losses and an increase in average body temperature $\left(0.6-0.76^{\circ}\right)$. Between 40 and $70 \%$ of the increase in heat production after injury could be accounted for by the van't Hoff $Q_{10}$ effect, secondary to elevation of the average body temperature. The energy equivalent of the increased urinary $\mathbf{N}$ excreted (allowing $110 \mathrm{~kJ} / \mathrm{g} \mathrm{N}$, West, 1961 ) accounted for only $24 \%$ of the increase in heat production over the first $4 \mathrm{~d}$ after injury. Respiratory quotient (RQ) measurements indicated that control and injured rats alike utilized fat as their main energy source (RQ 0.7-0.73).

Direct comparison of Cairnie's and Miksche's observations is misleading because of significant differences in experimental design. These are presented in detail (Table I) to illustrate the problems of interpretation which exist in much of the literature regarding changes in energy after injury.

The significance of changes in protein degradation after bone fracture in the rat and their relationship to energy expenditure remain unresolved. However, considerable indirect evidence has been obtained in nutritional studies on rats with burn wounds (Caldwell, 1961, 1962; Caldwell, Osterholm, Sower \& Mayer, 1959) and in calorimeter studies of burned rats (Caldwell et al. 1966) that increased proteolysis alone does not account for the measured post-injury increase in energy expenditure. Evaporative heat losses increased up to five times control values after thermal injury but no increment in sensible heat loss occurred. Total heat losses increased $47.6 \%$ above control values and were sustained, continuing beyond the $43^{\text {rd }}$ post-burn day. The increased protein excreted contributed only $20 \%$ of the total energy expenditure before and after burning (Caldwell, 1970). Cuthbertson's early hypothesis that protein was utilized exclusively as a fuel in order to meet increased energy needs after injury was therefore not supported by subsequent experimental evidence.

In man, studies were carried out with a practical indirect calorimetry system constructed for use in a clinical situation (Kinney, Morgan, Domingues \& Gildner, 
Table I. Comparison of the experimental conditions of rat calorimetry used by two sets of investigators (Caimie et al. 1957; Miksche \& Caldwell, 1967)

\begin{tabular}{|c|c|c|}
\hline Calorimeter & $\begin{array}{l}\text { Cairnie et al. (1957) } \\
23 \mathrm{~kg} \text { in adapted gradient } \\
\text { layer }\end{array}$ & $\begin{array}{l}\text { Miksche \& Caldwell ( } 1967 \text { ) } \\
\text { Single rat size, purpose-built } \\
\text { gradient layer }\end{array}$ \\
\hline Measurement period & $\begin{array}{l}22 \text { out of every } 24 \mathrm{~h} \\
\text { continuous measurement }\end{array}$ & 3 periods of $20 \mathrm{~min}$ per 24 \\
\hline Rats, number in calorimeter & $\begin{array}{l}9 \text { rats packed into boxes } \\
\text { within calorimeter chamber }\end{array}$ & Single \\
\hline Rats, number in study & $\begin{array}{l}9 \text { in calorimetry group, } 6 \text { in } \\
\text { separate metabolic cages. } \\
\text { Urine nitrogen estimated on } \\
\text { the latter }\end{array}$ & $\begin{array}{l}\text { 12 in calorimetry group. I } 2 \text { i } \\
\text { a separate metabolic group. } \\
\text { Urine nitrogen estimated on } \\
\text { latter }\end{array}$ \\
\hline Injury & $\begin{array}{l}\text { Single femur fracture, open } \\
\text { method }\end{array}$ & $\begin{array}{l}\text { Bilateral femur fracture, } \\
\text { closed method }\end{array}$ \\
\hline Feeding regime & $\begin{array}{l}\text { Rats restricted after fracture } \\
\text { to mean pre-injury ad lib. } \\
\text { intake }\end{array}$ & Ad lib. throughout \\
\hline Duration of urine collections & $24 \mathrm{~h}$ period & $\begin{array}{l}\text { (14.01-23.59 hours) io } \mathrm{h} \\
\text { post-prandial period }\end{array}$ \\
\hline Animal house temperature & $19 \pm 2^{\circ}$ & $25 \pm 1^{\circ}$ \\
\hline $\begin{array}{l}\text { Calorimeter operating } \\
\text { temperature }\end{array}$ & $\begin{array}{l}\text { ig }+0.3^{\circ} \text {. Below rat } \\
\text { thermoneutral zone }\end{array}$ & $\begin{array}{l}28 \cdot 4 \pm 0.23^{\circ} \text {. Within rat } \\
\text { thermoneutral zone }\end{array}$ \\
\hline $\begin{array}{l}\text { Dietary status of rats during } \\
\text { calorimetry }\end{array}$ & $\begin{array}{l}\text { Not fasted, fed during } \\
\text { calorimeter runs }\end{array}$ & $\begin{array}{l}\text { I } 8 \text { h post-absorptive during } \\
\text { calorimeter run }\end{array}$ \\
\hline
\end{tabular}

1964) on energy expenditure in relation to metabolic changes in a wide variety of surgical conditions (Kinney, Long, Gump \& Duke, 1968; Kinney, Long \& Duke, 1970a; Kinney, Long, Duke \& Gump, 1970b). Very small increases in energy expenditure, less than $10 \%$, occurred after elective surgery. Multiple bone fractures were followed by increases of ${ }^{15-30 \%}$ for up to 2-3 weeks. Major sepsis, such as peritonitis, caused increases of $20-50 \%$ and extensive full skin thickness burns caused the greatest and most sustained increases of up to $125 \%$ above predicted normal values.

Surgical patients (Kinney \& Roe, 1962; Roe \& Kinney, 1965) showed variations between their rise in body temperature and increase in resting metabolic rate similar to those observed in certain clinical infections (Du Bois, 1924) so making the application of the van't Hoff factor uncertain in the individual case.

In extensive burns, and other severely catabolic injuries, Kinney and his colleagues found that the increase in metabolic expenditure determined by daily indirect calorimetry was insufficient to account for the sustained weight loss of $0.3-0.6 \mathrm{~kg} / \mathrm{d}$ which took place. As with rats, protein provided only a small (12-22\%) proportion of the increased energy expenditure after injury, the majority of the energy requirements being met by oxidation of fat. Taking full allowance of 
all factors, they were able to account for only $60 \%$ of the weight lost after severe injury. They suggested that the remainder of the weight loss was due to the excretion of excess body water, but could not corroborate this.

Kinney presented evidence (Kinney et al. 1970a,b) that increased protein degradation occurred after injury in order to meet the body's increased demand for carbohydrate intermediates in the Krebs cycle via hepatic gluconeogenesis, rather than to meet increased whole-body energy requirements. Additional indirect calorimetry studies were devised to measure whole-body and splanchnic blood flow and oxygen consumption in patients with burns, and in patients with peritonitis to determine the aetiology of the hypermetabolism of injury (Gump, Price \& Kinney, $1970 a, b$ ). If due solely to the deamination of labile body protein it was argued that this would occur mainly in the liver. As the increased blood flow and oxygen consumption across the splanchnic viscera after injury and in infection accounted for only $4^{0-} 5^{0} \%$ of the total increase, it was thought that the hypermetabolism of this form of surgical fever involved tissues other than liver, and chemical reactions other than deamination and urea synthesis. Fat stores could be oxidized to meet energy needs in the state of semi-starvation often associated with injury, but protein represented the only sizeable reserve of carbohydrate intermediates and glucose precursors also essential for survival. Carbohydrate stores within the body were insignificant, and after even short periods of starvation body glucose needs are met by an increased liver production of glucose from protein precursors. Using an isotopic tracer technique (Spencer, Long \& Kinney, 197I), it was established that in the late recovery phase following severe injury, and in sepsis, both glucose oxidation and gluconeogenesis were increased (Long, Spencer, Kinney \& Geiger, 1971; Gump, Long, Killian \& Kinney, 1974) and that gluconeogenesis could not be suppressed by intravenous infusion of glucose (Long, Kinney \& Geiger, 1976). This suggested that after injury the normal neurohumoral regulation of gluconeogenesis with muscle and liver had ceased to be effective. The explanation may lie in the upset hormonal balance known to follow severe injury, in which increases in the 'catabolic' hormones, adrenaline, noradrenaline, corticosteroids, glucagon, and growth hormone predominate (Allison, 1974; Moore \& Brennan, 1975; Wilmore, Long, Mason \& Pruitt, 1976a; Alberti, Batstone \& Johnston, 1977).

It has been suggested that the increased proteolysis and gluconeogenesis of injury is caused by catecholamine-induced 'insulin resistance' in muscle tissue, which leads to impaired glucose and fat utilization (Clowes, O'Donnell, Ryan \& Blackburn, 1974; Clowes, O'Donnell, Blackburn \& Maki, 1976). Energy needs in muscle are then met by oxidation of the branch-chain amino acids producing excess alanine and other gluconeogenic precursors in the blood stream. Hepatic gluconeogenesis and ureagenesis is thereby stimulated (Odessey, Khairallah \& Goldberg, 1974). Therefore 'insulin resistance' and its effect on metabolic pathways in muscle makes available large quantities of glucose derived from muscle amino acid pools, providing in the short term, brain and other essential organs with a readily assimilated energy supply. This response becomes disadvantageous in the long term if muscle protein pools become depleted without 
replenishment, a situation which occurs in serious injury if a 'catabolic' endocrine climate with high circulating catecholamine levels is prolonged.

In the midst of these recent, complex and exciting biochemical developments does the calorimeter still have a role? The work already described represents what might be termed long term nutritional-energetic studies after injury. Used in this way, in rats, direct gradient layer, with combined indirect calorimetry has provided an essential first step in our detailed knowledge of the energetic consequences of injury. It is difficult to assess the accuracy of indirect calorimetry studies in patients, largely because of the problems of interpreting measurements where so many factors can vary.

The large insensible water losses from burned patients, resulting from heat damage to dermal vapour barriers (Moyer \& Butcher, 1967) has been assumed, since its discovery, to be the major cause of post-burn hypermetabolism. Gump \& Kinney (1970) challenged this view, quoting the work of Zawacki, Spitzer, Mason \& Jones (1970) who appeared to demonstrate no link between increases in evaporative water loss and increased metabolic rate after burn injury, though the indirect methods of measurement used make it difficult to draw firm conclusions from any of these studies. More recently Wilmore and his co-workers (Wilmore, Orcutt, Mason \& Pruitt, 1975; Wilmore et al. 1976a; Wilmore, Taylor, Hander, Mason \& Pruitt, $1976 b$ ) revived this notion. They built a special insulated chamber for heat exchange measurement in burned patients and, using indirect calorimetry and skin/core temperature measurements, concluded that these patients behaved as if their hypothalamic centre had been reset at a higher level than that required to counteract the evaporative heat losses of the burn. However, in the absence of accurate partitioned heat-loss studies using simultaneous direct and indirect calorimetry in burned patients, this indirect evidence cannot be regarded as conclusive.

Arturson, Danielson \& Wennberg (1977) continue to view the cooling load of accelerated water and heat losses as the most important single factor leading to a compensatory catecholamine-mediated increase in heat production inducing postburn hypermetabolism. The anticipated protein and weight losses did not occur after severe burns when patients (Davies, Liljedahl \& Birke, 1969; Davies \& Liljedahl, 1970; Davies, 1977) and experimental animals (Caldwell, 1970) were nursed at thermoneutral ambient temperatures $\left(30-32^{\circ}\right)$ (Tilstone, 1974). But Campbell \& Cuthbertson ( 1967 ) noted that this also occurred in rats after closed femur fracture where the cooling load was absent, and in patients with fractures (Cuthbertson \& Tilstone, 1968). The mechanism of this effect is not fully understood (Wilmore et al. 1976a,b). Although some of the reduction in weight loss found at the thermoneutral environmental temperatures could be related to reduced sensible heat losses (Caldwell, 1970), it is interesting that Liljedahl (1972) observed a marked reduction in the excretion of catecholamines when burned patients were treated at the higher ambient temperature. As Clowes et al. (1976) have suggested, this may decrease muscle insulin resistance, thereby sparing 
muscle protein. If valid the prospect of environmental control of body hormonal climate is appealing.

Kinney (1976) has summarized the current situation. The hypermetabolism of catabolic injury states might be due to alterations in any of the following categories: (A) Intermediate metabolism involving: protein turnover; specific dynamic action; gluconeogenesis; triglyceride metabolism. (B) Utilization of high energy bonds involving: increased demand for work; reduced work efficiency. (C) Heat metabolism involving: fever; increased heat losses. (D) Abnormal 'setting' of hypothalamic centre.

For practical reasons the application of calorimetry, even in categories $C$ and $D$, remains limited in injured patients to indirect techniques. At the present, accurate partitioned heat-loss studies can only be effectively performed in experimental animals. To be most informative, calorimetry must be carried out together with biochemical and other analyses in a multi-disciplinary approach to the problem of the response to injury.

\section{Experimental conditions}

In view of the widely differing environmental conditions and techniques previously employed in measuring the rat's response to thermal injury, a carefully controlled, reproducible rat model of untreated injury was sought which might be a useful parallel to the human response. This required at least a laboratory and animal unit with a closely controlled environment, a calorimeter to measure energy loss, accurate dietary intake information and continuous metabolic collections for biochemical estimations.

A purpose-built laboratory and animal house were designed to minimize stress from noise and the effects of handling. The animal house was air-conditioned to give controlled temperature and humidity, and continuous separate collection of urine and faeces was possible in ten of the cages. The animals were trained to accept the handling procedures, the feeding regime and the calorimetry conditions before the experiment began (Drury, Richards \& Brown, 1977). A common steady weight growth was taken as the criterion of successful training.

Because a thermal injury involves a large amount of evaporative water loss, an indirect and direct calorimetry system able to measure heat production and partition energy loss was designed (Carter, Shaw, Richards, Boyd \& Harland, 1975; Carter, Drury \& Richards, 1976). The calorimeter shown schematically in Fig. I has at its heart a gradient-layer box large enough to take a single rat. Three thousand thermocouples in the walls of the box give it a high enough sensitivity ( $\mathrm{mV} / 0 \cdot 36 \mathrm{I} \mathrm{W}$ ) to make it suitable for rat energy determinations. The box is ventilated by air flowing at a rate of 6-8 $1 / \mathrm{min}$ which has been conditioned for humidity via a humidifier and dew-point bath and for temperature using a water bath and heat exchangers. The energy loss to the air is calculated from the temperature difference across the box and added to the larger energy flow through the box walls gives, apart from small correction, the sensible heat loss of the animal. A differential hygrometer measures the water evaporating from the rat, 


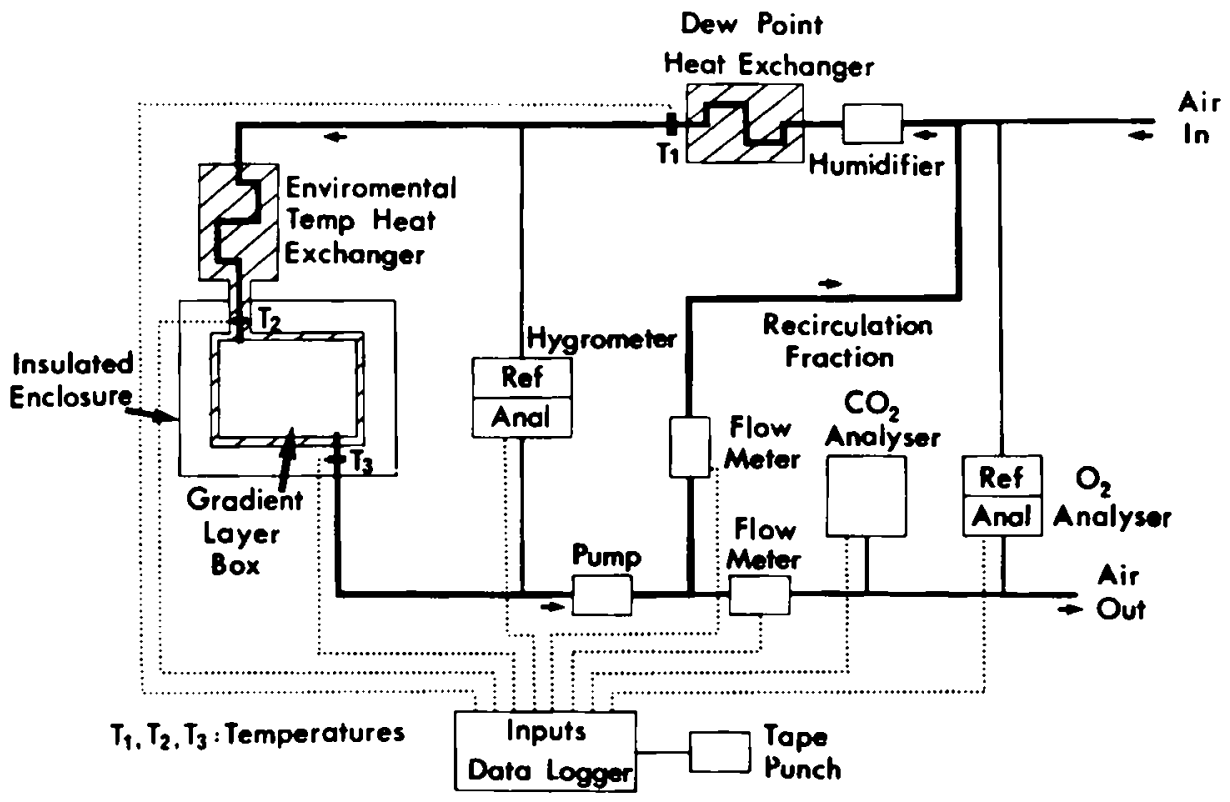

Fig. 1. A schematic diagram of the direct and indirect calorimetry system.

allowing calculation of its insensible heat loss. Oxygen consumption and carbon dioxide production are monitored to give the rate of heat production. All the instrumental outputs are scanned periodically using a data logger, the values being punched onto paper tape for later computer processing.

Calorimetry runs were made at the same time each day, lasting a minimum of $3 \mathrm{~h}$ with the rat at least $\mathrm{I} 2 \mathrm{~h}$ post-absorptive. Comparison of direct and indirect calorimetry has shown that if the values obtained during the first $40 \mathrm{~min}$ while the rat is settling and the apparatus equilibrating are ignored, agreement to better than $1 \%$ can be obtained. This suggested that the heat content of the animal was stable, at least after the first $40 \mathrm{~min}$. In their post-absorptive state the respiratory quotients of both burn and control groups fell in the range $0.69-0.73$.

The experimental animals used were male Wistar rats from a semi-inbred closed colony. A standard thermal injury of a $25 \%$ body surface area full thickness burn was used in all the experiments, the surface area being calculated using the formula:

$$
\text { surface area }=10.1 \times(\text { weight })^{2 / 3}
$$

The thermal injury was controlled in temperature, pressure and time using a Bunyan contact burn apparatus. The anaesthetized animals were branded only on shaved areas of anagen hair growth (Zawacki \& Jones, 1970) and the controls were also shaved. 


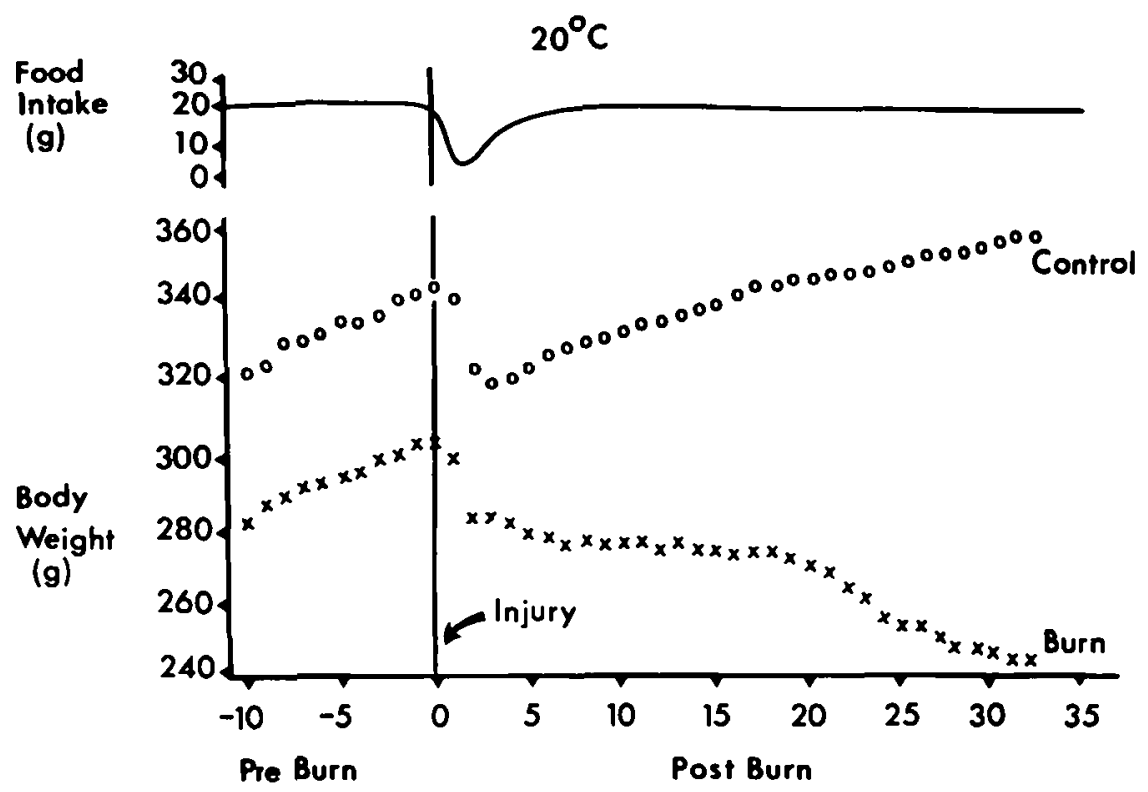

DAYS

Fig. 2. The food intake and weight graphs of burn and pair-fed control rats kept at $20^{\circ}$.

\section{Experiments and results}

In the first experiment, five rats with the standard injury and five pair-fed control rats were kept at $20^{\circ}$. Their food intake was restricted to $94 \%$ of their preburn average intake. There was an initial weight loss phase for both sets of rats as shown in Fig. 2. This was mainly caused by the decreased food intake of the injured animals and the pair-feeding. There followed a phase of slow weight loss by the burned animals while the controls resumed their preburn growth rate of approximately $2 \mathrm{~g} / \mathrm{d}$. After about $20 \mathrm{~d}$ the burned rats entered a third phase of faster weight loss. There could be three main possibilities for this increased rate of loss. (1) The energy losses of the animals increased requiring greater usage of energy substrates. (2) A larger proportion of the energy demands were being met from a lower energy/g source e.g. less fat and more protein being catabolized. (3) More water being excreted.

Fig. 3 shows the partitioned energy losses of the rats (the bars represent insensible heat loss and the height of the base of the bars sensible heat loss) with the dietary non-protein energy intake superimposed as an index of dietary energy available to the animal. The insensible heat losses rose to a steady level by about 10 $\mathrm{d}$ and thereafter showed no dependence on the state of the eschar which lost large amounts of water even though it was dry to the touch (Moyer \& Butcher, 1967). There is no increase in the apparent energy deficit over the 20-30 d period to account for the increased rate of weight loss. Figs 4 and 5 show the same experiment but following the progress of the rats over a longer period. The burned 


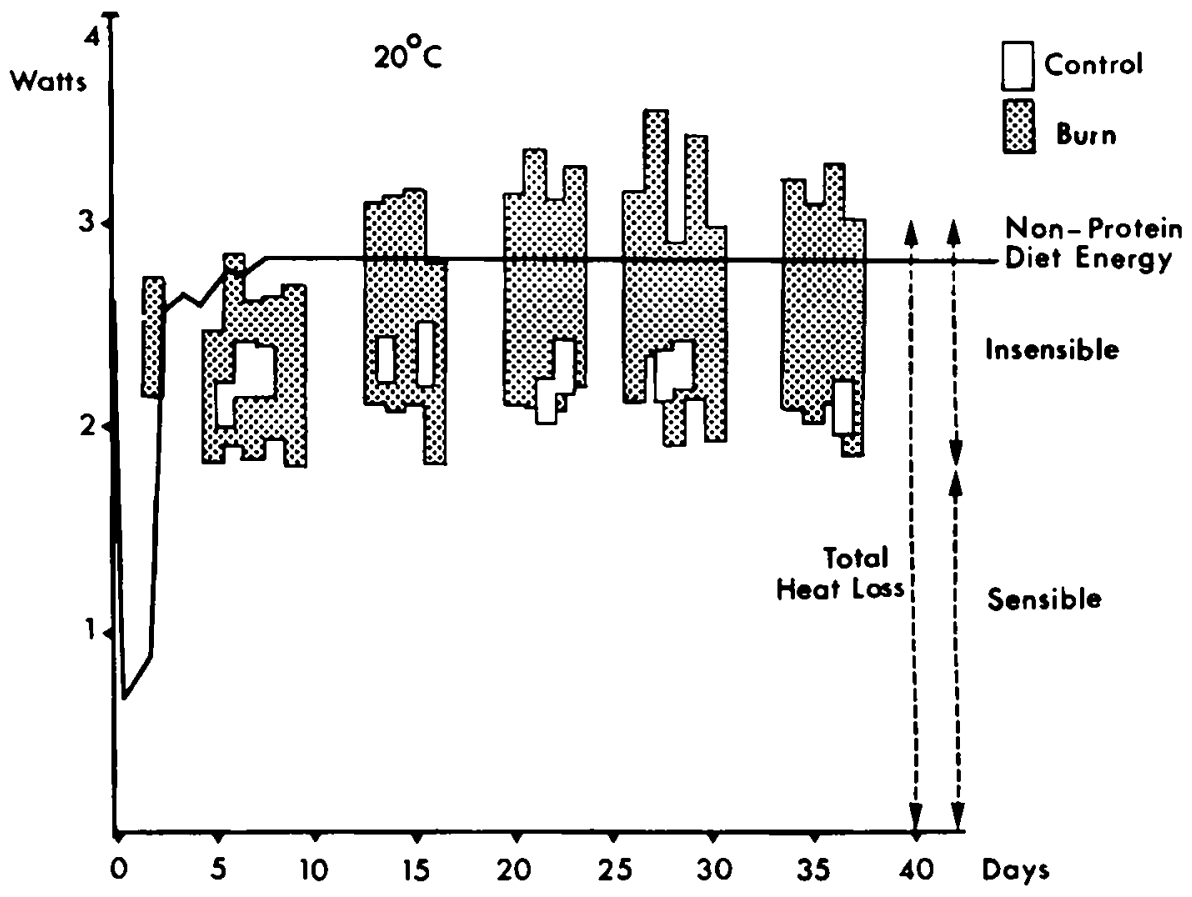

Fig. 3. The partitioned energy losses obtained from direct calorimetry on burn and control rats kept at $20^{\circ}$. The daily non-protein dietary energy intake is also shown.

animals, by losing a large portion of their mass, decreased their sensible heat loss until the total calorimetered loss approximately equalled their dietary intake. At this point of apparent energy balance their weight loss ceased, tending to support the representative nature of the calorimetry results.

Metabolic collections allowed continuous estimation of nitrogen balance in the rats. Unlike man, the rat is a continuously growing animal with no definite adult size, so that the animal is normally in a state of nitrogen retention. This was seen in both the burned and control animals, though the burned animals retained $20 \%$ (2. $2 \mathrm{~g}$ nitrogen) less than the controls over $35 \mathrm{~d}$.

At an environmental temperature of $30^{\circ}$ the response to the injury is different, as shown in Fig. 6. The animals were transferred from a temperature of $20^{\circ}$ to $30^{\circ}$ at the time of burning and were offered $94 \%$ of their average preburn ad lib. diet though their intake fell to approximately $70 \%$ of their $20^{\circ}$ consumption. The burned rats still did not grow as well as the controls but only a phase of slow weight loss was seen. There was no late phase of rapid weight loss. The energy values are shown in Fig. 7 with the dietary non-protein intake superimposed. The heat losses of all the animals at $30^{\circ}$ were consistently lower than the $20^{\circ}$ experiment.

The control animals had a period of raised heat loss over the first 10-15 d mainly due to an increment in sensible losses. This suggests that the rats require a period of acclimation on transfer from $20^{\circ}$ to $30^{\circ}$, though the shaving to which all 


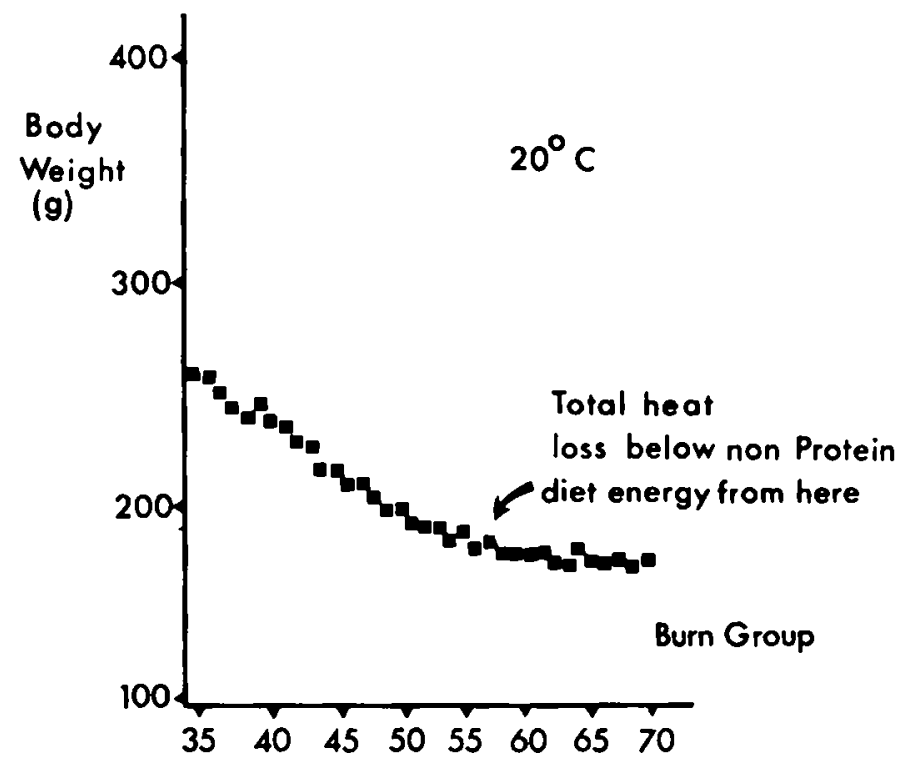

TIME DAYS POST BURN

Fig. 4. The weight graph of the burned rats kept at $20^{\circ}$ from $35-70 \mathrm{~d}$ post-burn.

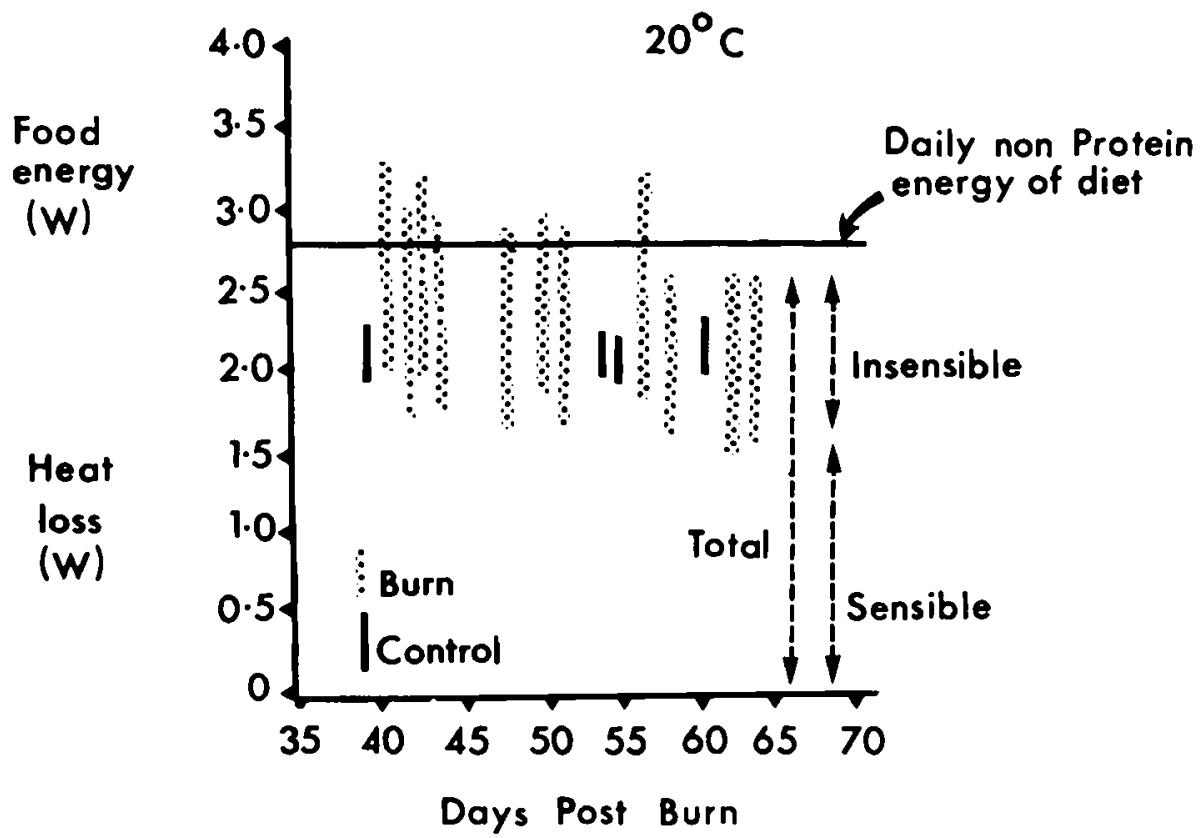

Fig. 5. The partitioned energy losses obtained from direct calorimetry on burn and control rats kept at $20^{\circ}$ over the period $35-70 \mathrm{~d}$ post-burn. The daily non-protein dietary energy intake is also shown. 


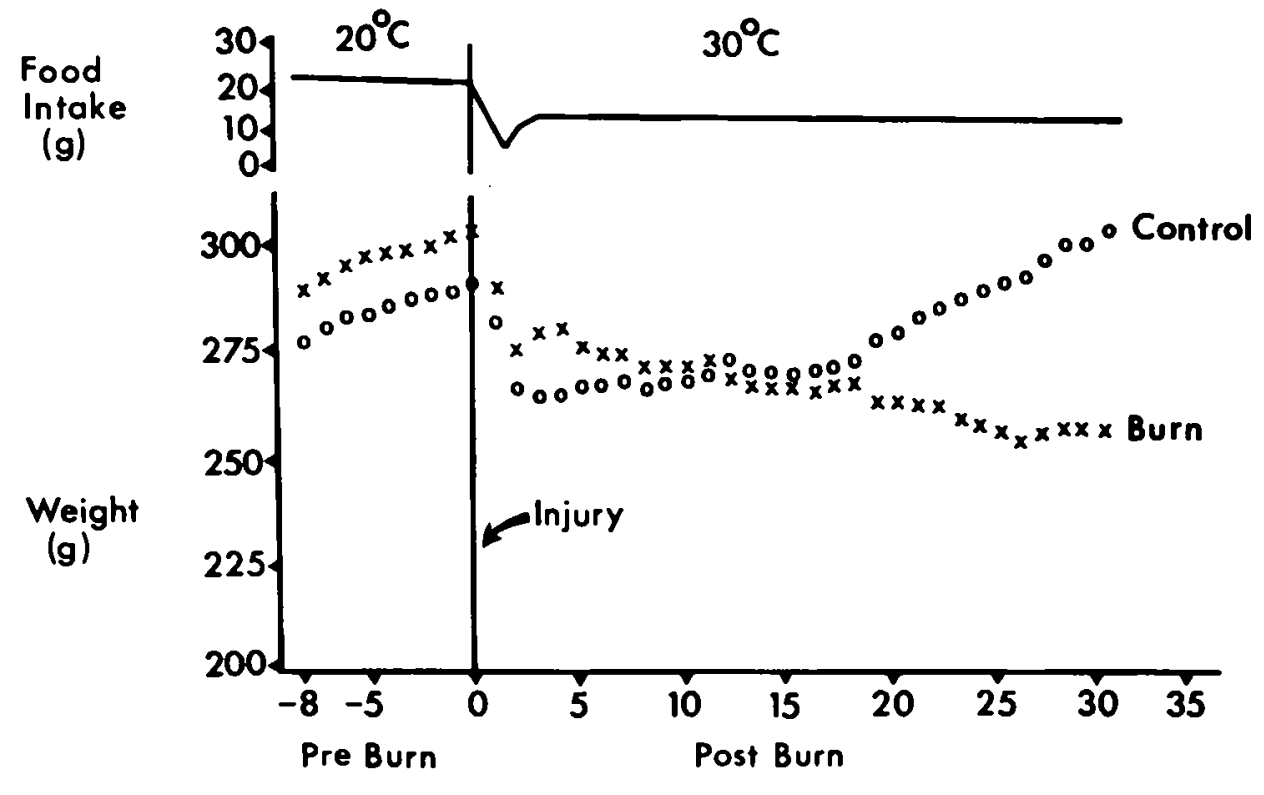

DAYS.

Fig. 6. The food intake and weight graphs of burn and control rats kept at $20^{\circ}$ preburn and $30^{\circ}$ post-burn.

animals are subjected at the point of injury will also increase the controls' sensible losses. The weight and energy balance relationships can be interpreted in a similar way to the $20^{\circ}$ experiment. When the calorimetered losses are approximately equal to the non-protein dietary intake, as with the control animals over the first IoI $5 \mathrm{~d}$, the growth rate is small. They only begin to grow at their preburn rate when they go into significant positive energy balance at around $15-20 \mathrm{~d}$. The slow rate of weight loss seen in the burned animals appears to be consistent with their continuing small energy deficit. Unlike the $20^{\circ}$ experiment, at $30^{\circ}$ both burn and control animals were in equal positive $\mathbf{N}$ balance.

The effects of energy changes on body composition were investigated in an experiment similar to the previous $20^{\circ}$ run. Six burned and five pair-fed controls gave a similar weight curve to Fig. 2, but the animals were sacrificed after $25 \mathrm{~d}$. Body composition analysis (Entenman, 1957; Folch, Lees \& Sloane-Stanley, I957; Varley, I967; Fleck, 1967) gave the amounts of water, fat and protein present in the carcases shown in Table 2. Compared with the controls, the burned animals had approximately $90 \%$ less fat, $30 \%$ less protein and $20 \%$ less water. Fat appears to be the major energy substrate utilized, protein only providing a small percentage of the tissue energy difference. No excess water has been lost, the ratio of total body water to protein being $3.06: I$ in the control animals and $3.42: 1$ in the burned. 


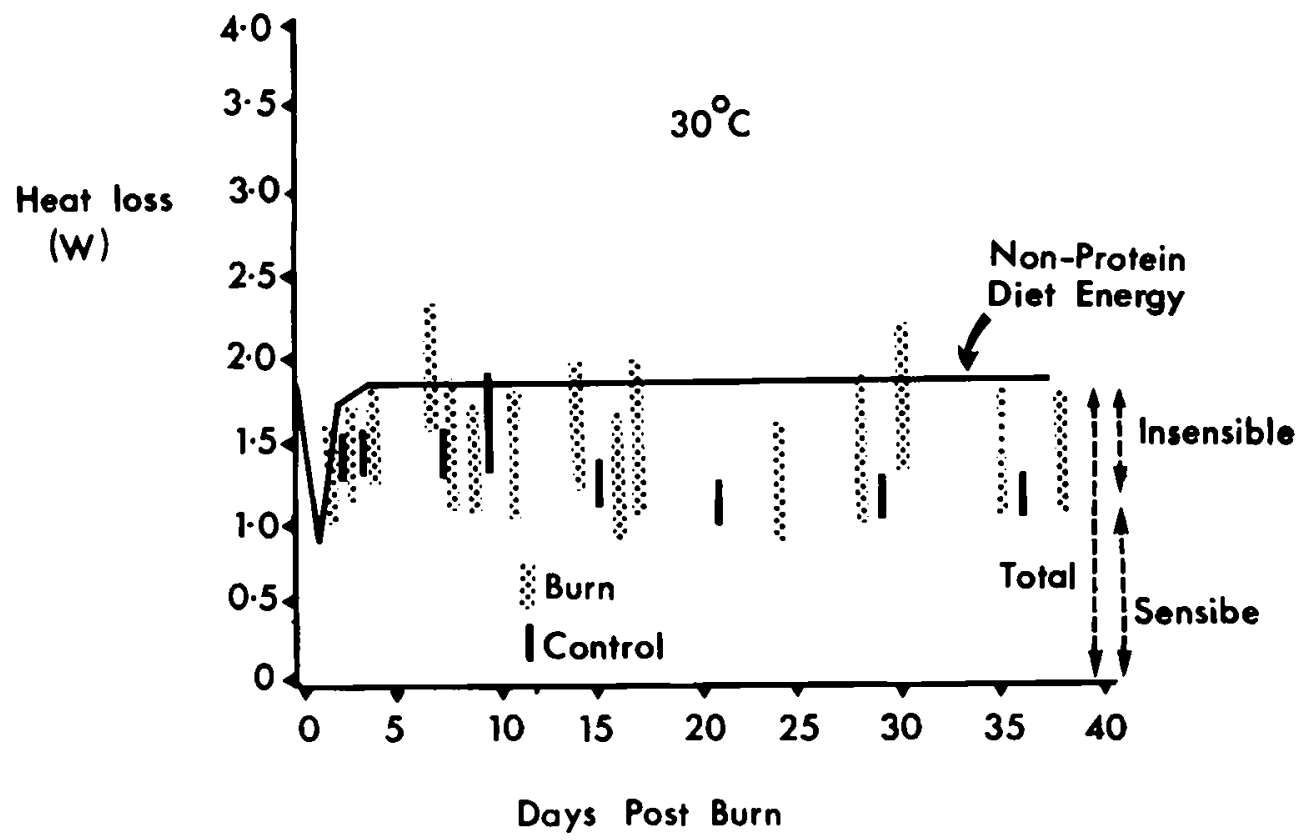

Fig. 7. The partitioned energy losses obtained from direct calorimetry on burn and control rats kept at $20^{\circ}$ preburn and $30^{\circ}$ post-burn. The non-protein dietary energy intake is also shown.

Table 2. Body composition of control and burned rats kept at $20^{\circ} \mathrm{C}$ under similar conditions, except that 6 of the rats were burned 25 days before sacrifice

Control mean

$\mathrm{N}=5$ s.e.m.

Burn mean

$\mathrm{N}=6$ s.e.m.

Control mean -

Burn mean

Significance $(P)$ of

difference between

means

(Wilcoxon Test)

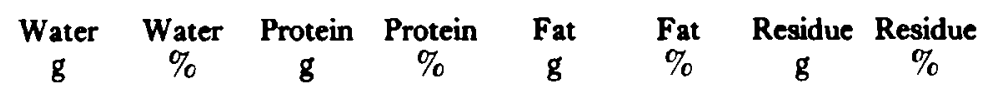

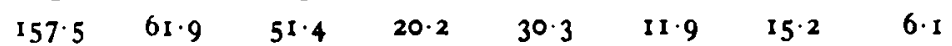

$\begin{array}{llllllll}9.97 & 0.5^{8} & 3.55 & 0.27 & 2.57 & 0.59 & 1.54 & 0.70\end{array}$

$\begin{array}{llllllll}124.3 & 69.2 & 36.4 & 20.4 & 3.8 & 2.1 & 15.0 & 8.2\end{array}$

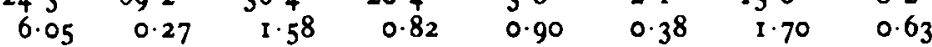

$\begin{array}{llllllll}33.2 & -7.3 & 15.0 & -0.2 & 26.5 & 9.8 & 0.2 & -2.1\end{array}$

$<0.01<0.01<0.01 \quad$ N.S. $<0.01<0.01 \quad$ N.S. N.S.

The measurement of catecholamines (Wood \& Mainwaring-Burton, 1975) at $20^{\circ}$ showed elevated values over an extended period for the burned animals compared with the controls (Fig. 8), in a similar way to man. Also shown on the figure are the insensible heat losses of the animal which decline at about the same point as the catecholamines. At this time the wound began to heal and the animal also started to put on weight and generally recover. 


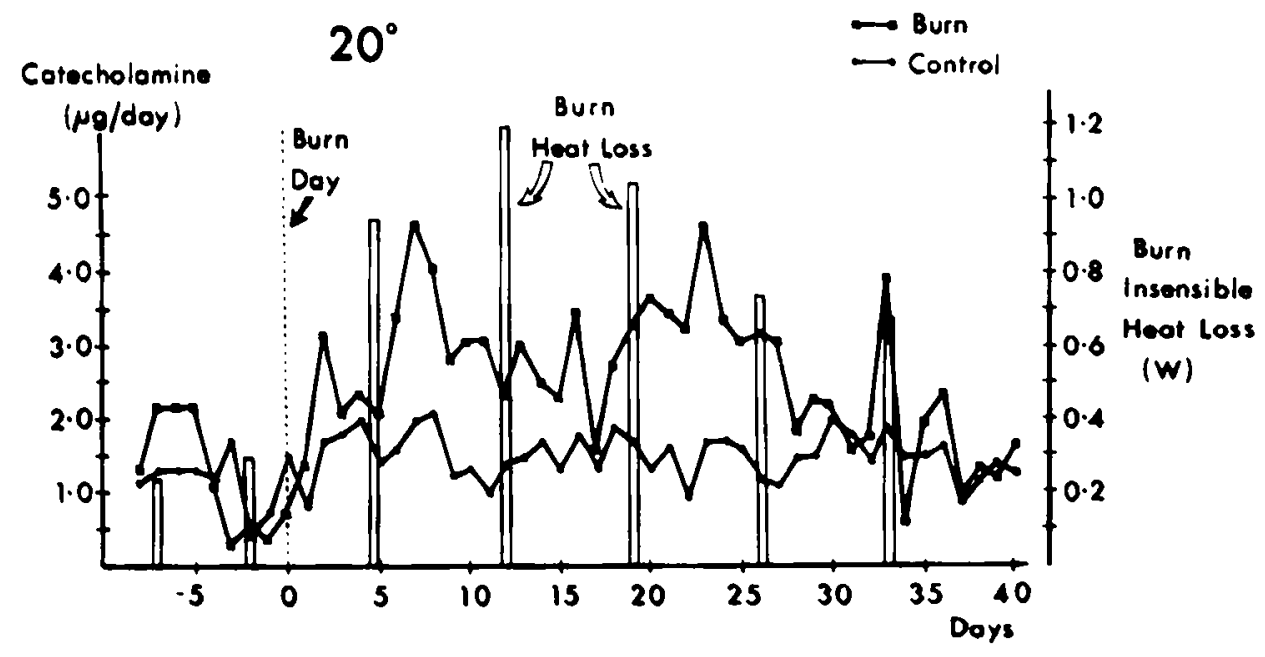

Fig. 8. The catecholamine excretion of two pair-fed rats, one burn and one control both kept at $20^{\circ}$. Also shown are the insensible heat losses of the burned animal.

\section{Discussion}

The experiments at both $20^{\circ}$ and $30^{\circ}$ show a close relationship between energy balance and growth rate in the rat. The ability to partition heat loss allows the identification of the unremitting evaporative heat loss from the burn and the response of the sensible heat loss to acclimation and partial shaving of hair. The third phase of increased weight loss in the $20^{\circ}$ experiment points to a change in energy substrate usage, as excess water excretion and increased energy deficit do not appear to be involved. Further work remains to be done to decide if the increased catecholamine excretion is linked directly to the evaporative water loss, as suggested by Arturson et al. (1977), to the whole body energy deficit or to some other stimulus.

Because calorimetry disturbs the feeding pattern and the rat's energy balance is only being measured at one point in its circadian rhythm, the values obtained may not be representative of the animal's average heat state. Differences in energy loss between animals and, in a longitudinal study, the change in energy losses in a particular animal, are not so markedly affected by these considerations.

The rat has major physiological differences from man including those of continuous growth and $\mathrm{N}$ retention already mentioned. This requires that control animals must be used to give an idea of the rat's normal response to feeding, calorimetry, etc. In man, injury response is normally judged against a control, though in this case it is a control with $\mathrm{N}$ balance and little weight change. However, the reproducibility of the rat's response along with the ability to study untreated injury with accurate body composition analysis should make it a useful analogue. Further investigation into the effects of wound covering, raised environmental temperature, direct biochemical intervention (e.g. administration of insulin) and dietary input are planned. The effects of these on energy substrate 
usage, protein synthesis and catabolism and general recovery will hopefully be of eventual use in patient management.

The initial construction of the calorimeter was financed by a grant from the Scottish Hospitals Endowment Research Trust (SHERT Grant No. 380) and the work continued with finance from a Medical Research Council grant (MRC Grant No. 976/490/S). The authors are grateful for the encouragement and facilities provided by Professors I. A. Boyd, L. H. Blumgart, J. M. A. Lenihan and H. G. Morgan.

\section{REFERENCES}

Alberti, K. G. M. M., Batstone, G. F. \& Johnstone, D. G. (1977). In Nutritional Aspects of Care in the Critically Ill, p. 225 [J. R. Richards and J. M. Kinney, editors]. Edinburgh: Churchill Livingstone.

Allison, S. P. (1974). In Parenteral Nutrition in Acute Metabolic Illness, p. 167 [H. A. Lee, editor]. London \& New York: Academic Press.

Arturson, G., Danielson, U. \& Wennberg, L. (1977). In Nutritional Aspects of Care in the Critically Ill, p. 625 [J. R. Richards and J. M. Kinney, editors]. Edinburgh: Churchill Livingstone.

Benzinger, T. H. \& Kitzinger, C. (1949). Rev. scient. Instrum. 20, 849.

Cairnie, A. B., Campbell, R. M., Cuthbertson, D. P. \& Pullar, J. D. (1957). Br. F. exp. Path. 38, 504 .

Caldwell, F. T. (1961). Surgery 49, 454.

Caldwell, F. T. (1962). Ann. Surg. 155, I 19.

Caldwell, F. T. (1 970). In Energy Metabolism in Trauma, p. 23 [R. Porter and J. Knight, editors]. London \& Edinburgh: Churchill Livingstone.

Caldwell, F. T., Osterholm, J. L., Sower, N. D. \& Moyer, C. A. (1959). Ann. Surg. 150, 976.

Campbell, R. M. \& Cuthbertson, D. P. (1967). Q. Fl exp. Physiol. 52, 114.

Carter, K. B., Drury, J. K. \& Richards, J. R. (1976). Med. biol. Eng. July, p. 465.

Carter, K. B., Shaw, A., Richards, J. R., Boyd, I. A. \& Harland, W. A. (1975). Med. biol. Eng. July, p. $55 \mathrm{I}$.

Clowes, G. H. A., O'Donnell, T. F., Blackburn, G. L. \& Maki, T. N. (1976). Surg. Clin. N. Am. 56, 1169 .

Clowes, G. H. A. Jr., O’Donnell, T. F., Ryan, N. T. \& Blackburn, G. L. (1974). Ann. Surg. I80, 684 .

Cope, O., Nardi, G. L., Quijano, M., Rovit, R. L., Stanbury, J. B. \& Wright, A. (1953). Ann. Surg. 137,165 .

Cuthbertson, D. P. (1930). Biochem. F. 24, 1244.

Cuthbertson, D. P. (1931). Biochem. F. 25, 236.

Cuthbertson, D. P. (1932). Q. $\mathcal{J} l$ Med. 25, 233 -

Cuthbertson, D. P. (1936). Br. Y. Surg. 23, 505.

Juthbertson, D. P. (1939). Q. Fl exp. Physiol. $29,18$.

Cuthbertson, D. P. \& 'Tilstone, W. J. (1 968). In Combined Injuries and Shock, p. 99 [B. Schildt and $L$. Thorn, editors]. Stockholm: Swedish Research Institute of National Defense.

Davies, J. W. L. (1 977). In Nutritional Aspects of Care in the Critically Ill, p. 595 [J. R. Richards and J. M. Kinney, editors]. Edinburgh: Churchill Livingstone.

Davies, J. W. L., Liljedahl, S.-O. \& Birke, G. (1969). Injury I, 43.

Davies, J. W. L. \& Liljedahl, S.-O. (1970). In Energy Metabolism in Trauma, p. 59. Ciba Foundation Symposium. [R. Porter \& J. Knight] London: Churchill.

Drury, J. K., Richards, J. R. \& Brown, J. J. (1977). J. Inst. anim. Tech. 28, 27.

Du Bois, E. F. (1924). In Basal Metabolism in Health and Disease. Philadelphia \& New York: Lea \& Febiger.

Entenman, C. (1957). In Methods in Enzymology III, p. 299 [C. Kaplan, editor]. New York: Academic Press.

Fleck, A. (1967). Proc. Ass. clin. Biochem. 4, 212.

Folch, J., Lees, M. \& Sloane-Stanley, G. H. (1957). F. biol. Chem. 226, 497. 
Gump, F. E. \& Kinney, J. M. (1970). Surg. Clin. N. Am. 50, I235.

Gump, F. E., Long, C. L., Killian, P. \& Kinney, J. M. (1974). F. Trauma 14, 378.

Gump, F. E., Price, J. B. \& Kinney, J. M. (1970a). Ann. Surg. 171, 321.

Gump, F. E., Price, J. B. \& Kinney, J. M. (1970b). Surgery Gynec. Obstet. 130, 23.

Kinney, J. M. (1976). In Metabolism and the Response to Injury, p. 121 [A. W. Wilkinson and D. P. Cuthbertson, editors]. Bath: Pitman Medical.

Kinney, J. M., Duke, J. H., Long, C. L. \& Gump, F. E. (1970b). F. clin. Path. $23,65$.

Kinney, J. M., Long, C. L. \& Duke, J. H. (1970a). In Energy Metabolism in Trauma, p. 103 [R. Porter and J. Knight, editors]. London: Churchill.

Kinney, J. M., Long, C. L., Gump, F. E. \& Duke, J. H. (1968). Ann. Surg. 168, 459.

Kinney, J. M., Morgan, A. P., Domingues, F. J. \& Gildner, K. J. (1964). Metabolism 13, 205.

Kinney, J. M. \& Roe, C. F. (1962). Ann. Surg. 156, 610.

Liljedahl, S.-O. (1972). In Parenteral Nutrition, p. 208 [A. W. Wilkinson, editor]. Edinburgh \& London: Churchill Livingstone.

Long, C. L., Kinney, J. M. \& Geiger, J. W. (1976). Metabolism 25, 193.

Long, C. L., Spencer, J. L., Kinney, J. M. \& Geiger, J. W. (1971). 7. appl. Physiol. 31, 110.

Miksche, L. W. \& Caldwell, F. T. (1967). Surgery 62, 66.

Moore, F. D. \& Brennan, M. F. (I975). In Manual of Surgical Nutrition, p. 169 [W. F. Ballinger, J. A. Collins, W. R. Drucker, S. J. Dudrick and R. Zeppa, editors]. Philadelphia \& London: W. B. Saunders.

Moyer, C. A. \& Butcher, H. R. (1967). In Bums, Shock and Plasma Volume Regulation. St. Louis: C. V. Mosby Co.

Odessey, R., Khairallah, E. A. \& Goldberg, A. L. (1974). Y. biol. Chem. 249, 7623.

Pullar, J. D. (1956). Abst. Communications 2oth International Physiological Congress, Brussels, p. 741 .

Pullar, J. D. (1957). Advmt. Sci., Lond. 13, 49.

Pullar, J. D. (1969). In International Encyclopaedia of Food and Nutrition, p. 47 I [D. P. Cuthbertson, editor]. London: Pergammon Press.

Richards, J. R. (1977). In Nutritional Aspects of Care in the Critically Ill, p. 273 [J. R. Richards and J. M. Kinney, editors]. Edinburgh: Churchill Livingstone.

Roe, C. F. \& Kinney, J. M. (1965). Surg. Ann. 161, 140.

Spencer, J. L., Long, C. L. \& Kinney, J. M. (197I). Ind. eng. Chem., fundam. 10, I.

Tilstone, W. J. (1974). In Parenteral Nutrition in Acute Metabolic Illness, p. 197 [H. A. Lee, editor]. London \& New York: Academic Press.

Varley, M. (1967). In Practical Clinical Biochemistry 4th Edn p. 419. New York: W. H. Medical Books Ltd \& Interscience Book Inc.

West, E. S. \& Todd, W. R. (Ig6r). Textbook of Biochemistry, p. 880. New York: Macmillan.

Wilmore, D. W., Long, J. M., Mason, A. D. \& Pruitt, B. A. (1976a). In Metabolism and the Response to Injury, p. 287 [A. W. Wilkinson and D. P. Cuthbertson, editors]. Bath: Pitman Medical.

Wilmore, D. W., Orcutt, T. W., Mason, A. D. \& Pruitt, B. A. (1975). F. Trauma 15, 697.

Wilmore, D. W., Taylor, J. W., Hander, E. W., Mason, A. D. \& Pruitt, B. A. (1976b). In Metabolism and the Response to Injury, p. 274 [A. W. Wilkinson and D. P. Cuthbertson, editors]. Bath: Pitman Medical.

Wood, W. G. \& Mainwaring-Burton, R. W. (1975). Clinica chim. Acta 61, 297.

Zawacki, B. E. \& Jones, R. J. (1967). Br. Y. Plastic Surg. 20, 347 .

Zawacki, B. E., Spitzer, K. W., Mason, A. D. \& Jones, L. A. (1970). Ann. Surg. 171, 236. 